\title{
French Haemovigilance Data on Platelet Transfusion
}

\author{
Béatrice Willaert Mai-Phuong Vo Mai Cyril Caldani \\ Agence Française de Sécurité Sanitaire des Produits de Santé (Afssaps), Saint Denis, France
}

\section{Key Words}

French hemovigilance - Apheresis platelet concentratece $\cdot$ Pooled platelet concentrate . Adverse reaction

\section{Summary \\ The Agence Française de Sécurité Sanitaire des Produits de Santé (Afssaps; French Health Products Safety Agency) is responsible, through its hemovigilance unit, for the organization and the functioning of the national hemovigilance network. In accordance with the French law, it receives all data on adverse transfusion reactions regardless of their severity. With the aim of evaluating the tolerance of two kinds of labile blood products (LBP), pooled platelet concentrates (PP) and apheresis platelet concentrates (APC), we screened the French national database from January 1, 2000 to December 31, 2006. We observed that the number of transfusion incident re- ports is more than twice as high with APC $(8.61: 1,000$ LBP) than with PP $(4.21: 1,000$ LBP). The difference be- tween these two ratios is statistically significant as shown by chi-square test ( $e=21.00$ with $\alpha=5 \%$ ). The risk to suffer adverse reactions of any type, except for al- loimmunization, is higher with APC, and the major type of diagnosis related to APC is allergic reaction (1:200 APC issued) even if those allergic reactions are rarely serious. The new French National Hemovigilance Commission should impel a working group evaluating this topic and above all the impact of additive solutions which have been used since 2005 to put forward preventives mea- sures.}

\section{Schlüsselwörter}

Hämovigilanz in Frankreich - Apheresethrombozytenkonzentrate - Gepoolte Thrombozytenkonzentrate . Unerwartete Nebenwirkung

\section{Zusammenfassung}

Die Agence Française de Sécurité Sanitaire des Produits de Santé (Afssaps) ist über ihre Hämovigilanzabteilung verantwortlich für die Organisation und das Funktionieren des nationalen Hämovigilanznetzwerks. In Übereinstimmung mit dem französischen Gesetz erhält sie alle Daten über unerwartete Transfusionsnebenwirkungen unabhängig von deren Schwere. Mit dem Ziel, die Toleranz gegenüber zwei Typen von labilen Blutprodukten Apheresethrombozytenkonzentrate (APC) und gepoolte Thrombozytenkonzentrate (PP) - zu evaluieren, überprüften wir den nationalen französischen Datenbestand für den Zeitraum 1. Januar 2000 bis 31. Dezember 2006. Dabei stellten wir fest, dass die Zahl der Berichte von Transfusionszwischenfällen bei APC mehr als doppelt so hoch war (8,61:1000) wie bei PP (4,21:1000). Dieser Unterschied war statistisch signifikant (Chi-Quadrat-Test; $e=21,00$ mit $\alpha=5 \%$ ). Das Risiko für unerwartete Nebenwirkungen ist mit APC mit Ausnahme der Alloimmunisation höher. Die häufigsten auftretende Nebenwirkung bei APC sind allergische Reaktionen (1:200 verabreichte APC), wenngleich diese allergischen Reaktionen selten schwerwiegend sind. Die neue französische Hämovigilanzkommission soll eine Arbeitsgruppe initiieren, die diese Fragestellung, besonders den Einfluss von additiven Lösungen seit 2005, untersucht, um die Präventivmaßnahmen zu verbessern.

\begin{tabular}{|c|c|}
\hline KARGER & (C) 2008 S. Karger GmbH, Freiburg \\
\hline $\begin{array}{l}\text { Fax +497614520714 } \\
\text { E-mail Information@Karger.de } \\
\text { www.karger.com }\end{array}$ & $\begin{array}{l}\text { Accessible online at: } \\
\text { www.karger.com/tmh }\end{array}$ \\
\hline
\end{tabular}




\section{Introduction}

For more than 14 years, hemovigilance has aimed to prevent the occurrence of adverse reactions (AR) related to the transfusion of labile blood products (LBP). In order to reduce the viral residual risk (lower donor exposure), apheresis platelet concentrates (APC) are more often applied in platelet transfusion ( 80.5 versus $19.5 \%$ ) than pooled platelet concentrates (PP). From 1995 to 2006, the amount of APC used in France has increased regularly: from 130,000 APC to 190,000 APC. On the other hand the amount of PP has decreased from 72,000 to 24,000 in 2002, but increased again to 43,000 in 2006. The present study aimed at evaluating the tolerance of these two kinds of LBP in terms of AR observed in recipients. We therefore screened the database of the national hemovigilance network that gives an exhaustive view of the AR notifications in France in combination with a complete traceability of the transfused LBP for AR possibly, probably or definitely attributable to the transfusion of these two types of platelet concentrates (PC) between January 1, 2000 and December 31, 2006.

\section{The French Hemovigilance System}

The Agence Française de Sécurité Sanitaire des Produits de Santé (Afssaps; French Health Products Safety Agency) is responsible for the organization and the functioning of the national hemovigilance network. In accordance with the French laws, all AR, regardless of their severity, are notified to the Afssaps by hemovigilance correspondents (in public and private hospitals as well as in blood establishments) on standardized forms (online reporting system). In France, we use five levels of seriousness and evidence each.

\section{Grade of Seriousness}

- Grade 4: death during or after transfusion.

- Grade 3: life-threatening AR.

- Grade2: long-term morbidity (i.e. above all transfusiontransmitted viral infection and alloimmunization).

- Grade 1: minor AR.

- Grade 0: inappropriate transfusion of LBP consecutive to one or several dysfunctions, without any clinical or biological consequence for the recipient.

\section{Evidence Levels}

- Level 4: certain = conclusive evidence for attributing the AR to the blood transfusion.

- Level 3: likely = evidence in favor of attributing the AR to the blood transfusion, without any other obvious causes.

- Level 2: possible = evidence is indeterminate for attributing the AR either to the blood transfusion or to alternative causes.

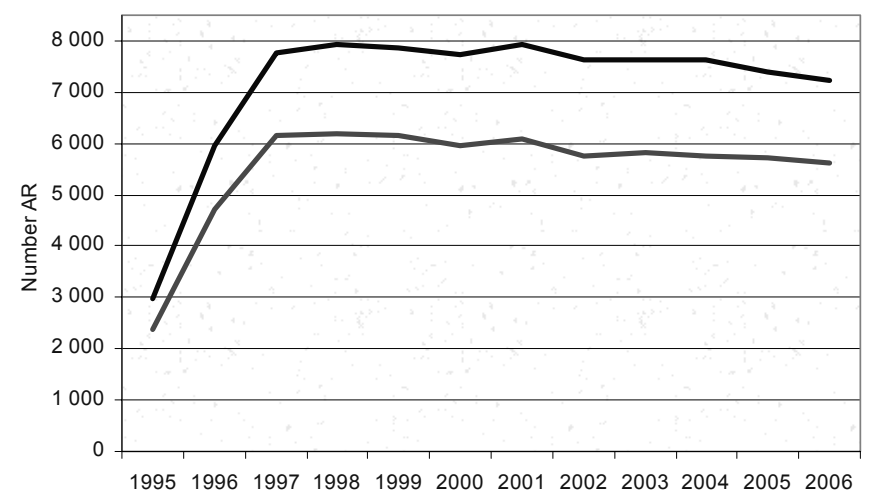

Fig. 1. Time series AR 1995-2006.-All notifications. - Notifications with evidence level $\geq 2$.

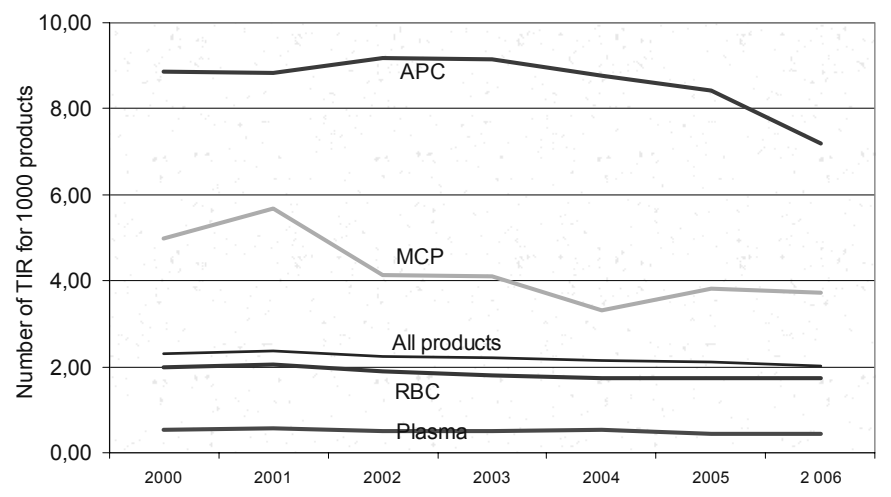

Fig. 2. Notification of adverse events, evidence levell $\geq 2,2000-2006$.

- Level 1: doubtful = other possible causes but no evidence for excluding the role of the blood transfusion in the occurrence of the AR.

- Level 0: excluded = conclusive evidence for attributing the AR to causes other than the blood transfusion.

\section{Requirements of Hemovigilance}

Requirements of hemovigilance are:

- the notification of suspected AR observed in a recipient to the competent authority (Afssaps),

- a high level of traceability, i.e. the ability to trace each individual unit of LBP from the donor to the recipient or disposal.

\section{Source of Data}

- Afssaps

- EFS (the French National Blood Service)

- CTSA (the Army blood center)

- Hemovigilance correspondents reporting AR. 
Table 1. Frequency of transfusion related deaths, evidence level $\geq 2$ complete investigations (France 2000-2006)

\begin{tabular}{lrrrrrr}
\hline & $\begin{array}{l}2000- \\
2006\end{array}$ & ACP & PP & 1 for xx LBP & 1 for xx APC & 1 for xx PP \\
& 27 & 1 & 1 & 656,160 & $1,251,390$ & 210,630 \\
\hline TACO & & & & & & \\
$\quad$ Immunologic & 16 & 4 & 0 & $1,107,440$ & 312,870 & \\
$\quad$ imcompatibility & 16 & 4 & 0 & $1,107,440$ & 312,870 & \\
Unknown & 12 & 6 & 0 & $1,476,580$ & 208,570 & \multirow{2}{*}{ TRALI } \\
TTBI & 9 & 6 & 1 & 198,770 & 208,570 & 210,630 \\
Allergy & 5 & 1 & 0 & $3,543,790$ & $1,251,390$ & \\
Other immediate TIR & 8 & 1 & 0 & $2,214,870$ & $1,251,390$ & \\
Hemosiderosis & 2 & 0 & 0 & $8,859,480$ & & \\
Plasmodium falcipurum* & 1 & 0 & 0 & $17,718,960$ & & \\
Total grade 4 & 96 & 23 & 2 & 184,570 & 54,410 & 105,310 \\
\hline
\end{tabular}

TACO = Transfusion-associated circulatory; TRALI = transfusion-related acute lung injury; TTBI = transfusion-transmitted bacterial infections; TIR = transfusion incident reports.

*One Plasmodium falciparum declared lately for 2006, i.e. 2 AR for the period 2000-2006 and an incidence ratio of 1 for 8859480 LBP.
Table 2. Notification, evidence level $\geq 2$ complete investigations, 2000-2006

\begin{tabular}{lrll}
\hline LBP & LBP issued & $\begin{array}{l}\text { AR/1,000 } \\
\text { LPB }\end{array}$ & $\begin{array}{l}\text { AR grade 4 / } \\
100,000 \text { LBP }\end{array}$ \\
\hline RBCC & $14,098,804$ & 1.85 & 0.50 \\
APC & $1,251,391$ & 8.61 & 1.84 \\
PP (MCP) & 210,628 & 4.21 & 0.95 \\
Plasma & $1,896,460$ & 0.50 & 0.05 \\
\hline
\end{tabular}

$\mathrm{RBCC}=$ Red blood cell concentrate.

Table 3. Notification of adverse events, evidence level $\geq 2,2000-2006$

\begin{tabular}{lll}
\hline & $\begin{array}{l}\text { AR / 1,000 } \\
\text { APC }\end{array}$ & AR/1,000 PP \\
\hline FNHTR & 1,617 & 0,883 \\
Allergy & 5,001 & 1,595 \\
Alloimmunization & 0,292 & 0,864 \\
Unknown & 0,797 & 0,351 \\
Immunologic imcompatibility & 0,391 & 0,370 \\
Transfusion inefficiency & 0,244 & 0,062 \\
TACO & 0,062 & 0,024 \\
Virus infection & 0,002 & 0,000 \\
Other immediate AR & 0,121 & 0,009 \\
TTBI & 0,037 & 0,033 \\
TRALI & 0,033 & 0,005 \\
Other delayed AR & 0,015 & 0,000 \\
\cline { 2 - 3 } All AR & 8,612 & 4,211 \\
Death & 0,018 & 0,009 \\
\hline
\end{tabular}

FNHTR $=$ Febrile nonhemolytic transfusion reaction; TACO $=$ transfusion-associated circulatory; TRALI $=$ transfusion-related acute lung injury; TTBI $=$ transfusion-transmitted bacterial infections.

\section{Results}

From 1995 to 2006, about 32,074,000 LBP were transfused, and 85,051 AR associated with transfusion were registered. Until 1999, the AR/LBP rate had increased, and then had remained stable between 2.8 and 3 per 1,000 LBP. Thus, our results included data from 2000 to 2006 (fig. 1).

On average we have received 7,500 notifications of AR/year, more than $73.2 \%$ of the notifications were AR of minor gravity (grade 1$)$.

From 2000 to 2006, there were 96 deaths, with an evidence level from possible to certain, under complete investigation. Transfusion-associated circulatory overload (TACO) is the most common cause of transfusion-related death. Before 2002, transfusion-related acute lung injury (TRALI) were not individualized on the reporting form. Approximately half of the deaths were of evidence level 2. Frequency of death with APC is twice as high as with PP (1 death in 54,410 APC versus 1 death in 105,310 PP issued (table 1)).

All notifications of AR (evidence level 2, 3, 4) from 2000 to 2006 were reported to blood products issued. We observed that the number of transfusion incident reports (TIR) is more than twice as high with APC (8.61:1,000 LBP) than with PP (4.21:1,000 LBP). The difference between these two ratios is statistically significant as shown by chi-square test $(\mathrm{e}=21.00$ with $\alpha=5 \%$ ) (table 2 ).

The respective ratios for AR due to transfusion-transmitted bacterial infections (TTBI) are 0.0328:1000 APC and 0.0285:1000 PP, being not significantly different according to chi-square analysis $(e=0.320$ with $\alpha=5 \%)$.

It could also be shown that the risk to suffer AR of any type, except for alloimmunization, is higher with APC than with PP, even though most of the AR (93\%) are not serious (fig. 2).

The most frequently observed AR related to APC and PP 
transfusion were allergic reactions. 10,025 allergic reactions were reported 6,258 of which were associated with APC transfusion. The risk of allergic reactions subsequent to APC and PP transfusion is 1:200 and 1:630, respectively (table 3 ).

\section{Conclusions and Discussion}

The data of the French hemovigilance show that APC transfusion appears to be the greatest risk factor for AR of the 'allergy' type even if it should be remembered that allergic reactions are rarely serious.

Nevertheless, only APC permits the manufacturing of an HLA-compatible PC.

Since 2005, a slight decrease in the number of notified allergic reactions has been observed with APC. The impact of platelet additive solutions should be evaluated with the benefit of hindsight.

The new French national hemovigilance commission should impel a working group evaluating the topic of allergy and APC to put forward preventive measures. 